\title{
Environmental Injustices in Central and Eastern Europe: The Minority Pitfall
}

\author{
Csaba Varga \\ Department of Environmental Health, Institute of Public Health Medicine, Faculty of Medicine, University of Pécs, Pécs, 7426, Hungary
}

\begin{abstract}
The author calls the attention to the need of historical approach in human environmental studies - especially on inequities and environmental injustices - in Central and Eastern Europe. Different confounders should be considered reflecting the specific historical background of the present environmental and public health situation of the region. No deep analysis can be performed without studying the situation of ethnic and national minorities. These minorities are often subjects of environmental injusticies as well. The author demonstrates examples from the scientific literature to improper conclusions as consequences of neglecting geographic and historical facts. References to articles written in small languages may be another confounder due to the risk of mistranslations. From the disproportional environmental exposures (caused by historical or political hostilities) via the lack of availability of health care in mother tongue to the possible genetic differences of minorities can have significant impact at all levels of environment-health interactions that should be considered in the European public health studies.
\end{abstract}

Keywords Environmental Injustice, Central And Eastern Europe, National Minority, Ethnic Minority, Confounder

\section{Introduction}

The research on environmental protection and health has called the attention to the close relationship among environmental pollution and low socio-economical state, from the turn-of-the-century. Several - mainly American - authors exactly proved that ecologically hazardous sites and facilities (toxic waste dumps, landfills, large emitters, etc.) are disproportionally located and concentrated in the neighbourhood of disadvantaged populations[1,2]. It means, lower social state determines lower quality of the available environment as well. The European studies, however, indicate another aspect of the issue.

\section{Environmental Justice/Injustice, the Definition}

The specific historical-political-geographic conditions of some regions of the continent required a more exact definition of the environmental (in)justice[3,4]. A coherent definition was worked out by a consensus conference held by the Central European University, Budapest: "An environmental injustice exists when members of disadvantaged, ethnic, minority or other groups suffer disproportionately at

* Corresponding author:

chemsafety@freemail.hu (Csaba Varga)

Published online at http://journal.sapub.org/env

Copyright (C) 2012 Scientific \& Academic Publishing. All Rights Reserved the local, regional (sub-national), or national levels from environmental risks or hazards, and/or suffer disproportionately from violations of fundamental human rights as a result of environmental factors, and/or denied access to environmental investments, benefits, and/or natural resources, and/or are denied access to information; and/or participation in decision-making; and/or access to justice in environment-related matters[5]."

\subsection{Regional Adaptation of the Concept}

Recently, several studies have been performed and published on the environmental injustice in environmental management involving its health consequences in the Central and Eastern European (CEE) countries. Other studies have focused on the inequalities and inequities of populations in association with unhealthy habits and lifestyle in the new EU member states. They emphasize especially the social aspects of the issue: the role of socio-economic, cultural, etc. determinants. Evaluating some other European and US data their conclusions can be considered plausible.[5-7]

\section{The Historical Confounder}

Reading the articles critically, we should call attention to another aspect of inequities which cannot be regarded either as a socio-economic or environmental factor. It can be called "historical confounder". In the CEE region - and possibly elsewhere in the world as well - human populations, i. e. "nations" have been subjects of a significant burden rooting in the history. That is why the ethnic map of this region 
forms a multicoloured patchwork with a sophisticated pattern of national minorities. This situation and the consequent national hostilities (German-Polish, German-Czech, PolishRussian, Baltic-Russian, Little Entente ${ }^{1}$-Hungarian, etc.) is the surviving product of the peace treaties closing the two world wars.

The primary subjects of the environmental injustices may be the national minorities in CEE. These minorities were mainly products of the 20th century's stormy history, when suddenly a juvenile or foreign state started to rule millions of people, depending on the interests of great powers or their little allies. That is, they are organic part of an existing (neighbouring) nation, but are frequently only second class citizens of another state[8]. (One can find such territories both enclaves and compact zones along the borders - from Kaliningrad (Königsberg) to Kosovo, from Gdansk (Danzig) to Moldavia (Bessarabia) in great extent[4, 9]. Several national minorities have been pressured morally, culturally (and sometimes physically) by the majority population supported by the nationalist or ultranationalist political elite. The state constitutions of these countries frequently neglect the national identities of these citizens defining them simply Romanian, Czech, Slovak, Ukrainian, etc. Sometimes, even their right to the native land is questionable for the political extremists. At the 2nd half of the 20th century, the imbalanced industrialization focused especially onto these territories. The environmental hot-spots concentrated to the occupied lands inhabited by "strangers" who neither have the right to the territorial autonomy, healthy environment, proper education, nor the fair medical care ${ }^{2}$

\subsection{No Deep Analysis without Being Aware of Historical and Political Facts}

WHO experts examined environmental injustice in waste management in Western and Central European countries[6]. Nevertheless the authors' analysis is proper in general, but is valid only with restrictions to the CEE region. For instance, unexpected data from Slovakia can indicate the specificities of the small new ${ }^{3}$ countries. As the authors outlined close correlation was found between lower socio-economic state and higher waste exposure in Italy and the UK, but an inverse relationship was described in Slovakia. The historicaldemographic facts, however, offer a plausible explanation. In the present Slovakia, $14.22 \%$ of the 5.38 million inhabitants is national or ethnic minority. As the census of 2001 determined: the number of Hungarians was 520 thousand (and 573 thousand by mother tongue)[12]. Landfills are

\footnotetext{
${ }^{1}$ Little Entente: Mutual defense arrangement among Czechoslovakia, Yugoslavia and Romania during the the period between World Wars I and II. It was directed against German and Hungarian interests and revenge in the Danube River basin (Encyclopaedia Britannica).

${ }^{2}$ Health care in non-native language is a significant disadvantage indicated by well-defined health indices. One can compare the situation of Swedish language in the Finnish health care system [10] and Hungarian in the Slovak medical institutions [11]

${ }^{3}$ The first, separate state of the Slovaks in the history was the short-living Tiso's Slovakia during the WWII, but it became a real independent country only in 1993.
}

rather located in the plain areas which are dominated by the Hungarian minority in this country. The biggest part of the country is highland populated almost exclusively by Slovak people, but mountains are not favourable for construction of landfills. In this case, the geographical differences simply explain the inverse results, assuming higher living standards in the plain territories.

In other words, the issue is much more difficult than deprivation itself. In some countries the geographical facts, in other countries the official environmental policy causes disproportional environmental risks for the subpopulations [13].

\subsection{Ethnic vs. National Minority and the "Translation Confounder"}

The major ethnic minority in the CEE region is the multiply handicapped Roma (Gypsy, Romany) population. They are also involved in the "waste management issue". Unfortunately, sometimes, relevant data published in minor languages, in local journals can cause misinterpretations. American authors tend to disturb the Balkan and the CEE countries; or the Visegrád-4 and post-Soviet states; or ethnic and national minorities[9,13]. The WHO study, [6] cites improper facts about Roma people from Hungary. These populations gave up their traditional migratory lifestyle appr. 60 years ago, in consequence of the pressure by the communist state. Accordingly, they do not live in "camps often settled on contaminated sites" as the report writes, the county inhabitants live in colonies in the outskirts of towns and villages, while others in slums of bigger cities. Unfortunately, their hazardous environment and low hygienic standards are mainly developed by themselves. (See the accidental case of lead poisoning in a population[4]). These Roma colonies are not even similar as known from Emir Kusturica's movie "Time of the Gypsies" (1989)[14]. These latter were (?) characteristic to Italy and France as an early form of illegal waste business operated by Yugoslav Gypsies that time. The other Eastern Bloc Gypsies "behind the iron curtain" have never been so mobile. The wrong citation of the Hungarian National Public Health Service's report[15] by the WHO report may otherwise be based on misunderstanding: "15\% of the 767 Roma colonies for a total of 3 million persons" should assume much more inhabitants in Hungary, which number is properly only 10 million. Correctly, the 767 colonies are located in 530 Hungarian settlements with altogether 3 million inhabitants. Only 4.7\% (138 000) of them live in Roma colonies. The difference is more than significant.

Similar questions are generated by the studies from the multiethnic CEE countries, see e.g. the recent article of Rosicova and coworkers[7]. During studying regional distribution of alcohol-related mortality in Slovakia, they completely forgot about national minorities. For example, the aforementioned Hungarian minority lives in vast majority in two well-defined districts of Slovakia. This fact was not indicated in the authors' maps they were working with. There may be significant socio-cultural differences in the 
background of data from the lifestyle, nutrition (and other confounders) up to the genetic constitution (metabolic alterations). These factors may highly modify the results, especially considering that Hungarians are not related to the surrounding Latin, Slav or German nations[16]. Therefore, this type of simple diversification - "Roma or Slovak" population in Slovakia - drives the authors to a dead-end street. It may be a strange survival of the official homogenization policy of the former nationalist-communist regimes in the contemporary science that should be avoided by all means.

\section{Conclusions}

In conclusion, "historical" or "minority" injustices mean possible pitfalls of European studies on the environmental justice, inequites and inequalities. From the disproportional environmental exposures (caused by historical or political hostilities) via the lack of availability of health care in mother tongue to the possible genetic differences of minorities - as compared to the majority population - may handicap these groups. In brief, disadvantageous situation of some European minorities can be demonstrated at all levels of environment-health interactions therefore studies should consider and emphasize the special historical background, as well.

\section{Conflict of Interest}

The author declares that he has no conflict of interest.

\section{REFERENCES}

[1] D. R. Faber and E. J. Krieg (2002) Unequal exposure to ecological hazards: environmental injustices in the Commonwealth of Massachusetts. Environ Health Perspect 110 (suppl 2): 277-288

[2] P. M. Shepard, M. E. Northridge, S. Prakash and G. Stover (Eds) (2002) Advancing Environmental Justice through Community-Based Participatory Research [Monograph]. Environ Health Perspect 110 (suppl 2):139-327

[3] C. M. Briggs (2005) Environmental Justice, Risk, and Public Health studies in Central and Eastern Europe. Hung Epidemiol 2:283-288

[4] C. Varga, I. Kiss and I. Ember (2002) The lack of environmental justice in Central and Eastern Europe. Environ Health Perspect 110:A662-663
[5] T. Steger (2007) Making the case for environmental justice in Central and Eastern Europe. Central European University (CEU) Budapest

[6] M. Martuzzi, F. Mitis and F. Forastiere (2010) Inequalities, inequities, environmental justice in waste management and health. Eur J Pub Health 20:21-26

[7] K. Rosicova, A. M. Geckova, M. Rosic, E. N. Speybroeck, J. W. Groothoff and J. P. vanDijk (2011) Socioeconomic factors, ethnicity and alcohol-related mortality in regions in Slovakia. What might a tree analysis add to our understanding? Health and Place 17:701-709

[8] C. Varga (2011) A History-based Environmental Health: On the frontiers of Ecology, Public Health and History. WebmedCentral ECOLOGY;2(3):WMC001701

http://www.webmedcentral.com/wmcpdf/Article_WMC0017 01.pdf Accessed 5 September 2011

[9] C. Varga and I. Ember (2000) Comments on "The worst of both worlds: poverty and politics in the Balkans." Environ Health Perspect 108:A494

[10] L. Vincze (2008). A svéd nyelv helyzete a finn egészségügyi rendszerben. [The Swedish language in the Finnish health care system] MONY 2008 01 A svéd Vincze.pdf www.orvosinyelv.hu Accessed 5 September $201 \overline{1}$

[11] L. Vincze (2006). Nyelvhasználati nehézségek Szlovákia egészségügyi intézményeiben. [Problems with the use of language in the medical institutions of Slovakia] MONY 200601 Nyelvh Vincze.pdf www.orvosinyelv.hu Accessed 5 September 2011

[12] R. Dohányos, G. Lelkes and K. Tóth (2004) Nemzeti és etnikai kisebbségek Szlovákiában [National and ethnic minorities in Slovakia] Fórum-Lilium Aurum, Somorja-Dunaszerdahely

[13] C. Varga, I. Ember, E. Murányi and I. Kiss (2012) Historical public health in Central Europe with special reference to Hungary. Long-term environmental effects of a historical cataclysm. J Pub Health Res 1:45-50, doi:10.4081/jphr.2012.e9

[14] V. J. Brown (1999) The worst of both worlds: poverty and politics in the Balkans. Environ Health Perspect 107: A606-613

[15] E. Kusturica (1989) Dom za vešanje [Time of the Gypsies], Yugoslav film

[16] G. Ungváry, A. Odor, M. Bényi, S. Balogh and É. Szakmáry (2005) Romatelepek Magyarországon - gyermekek egészségügyi ellátása, higiénés viszonyok [Gipsy colonies in Hungary - medical care of the children and hygienic situation] Orv Hetil 146(15): 691-699

[17] C. R. Guglielmino and J. Béres (1996) Genetic structure in relation to the history of Hungarian ethnic groups. Hum Biol $68: 335-355$ 